Eur. J. Clin. Chem. Clin. Biochem.

Vol. 32, 1994, pp. 691-696

(c) 1994 Walter de Gruyter \& Co.

Berlin - New York

\title{
Specific Interference with the Determination of the Tumour-Associated Glycoprotein 72 by Human Anti-Idiotypic Antibodies Formed after Treatment with the Anti-Tumour-Associated Glycoprotein 72 Antibody B72.3
}

\author{
By J. Reinsberg ${ }^{1}$, Birgit Gast, J. Schmolling, U. Wagner and D. Krebs \\ Zentrum für Frauenheilkunde und Geburtshilfe, Universität Bonn, Bonn, Germany
}

(Received April 5/July 4, 1994)

Summary: Recorded concentrations of the tumour-associated glycoprotein 72 (TAG-72) in ovarian cancer patients after repeated infusion of the antibody B72.3 were found to be falsely elevated when measured with an homologous immunometric assay involving the anti-TAG-72 antibody B72.3 (Test 1), or with an heterologous assay involving CC49 capture and B72.3 detector antibodies (Test 2). Test 1 yielded falsely elevated values up to $10^{4} \mathrm{kU} / 1$. Test 2 gave slightly false positive elevations up to $10^{2} \mathrm{kU} / 1$ for only some of the samples with very high false-positive values in Test 1 . The interfering serum components bound to Protein G-Sepharose and could be precipitated with perchloric acid or by heating serum samples to $100^{\circ} \mathrm{C}$. Addition of non-specific murine immunoglobulins only partly suppressed false-positive values in both tests. Our results suggest that this interference is caused by human anti-B72.3 IgG induced by B72.3 application, which to some extent specifically binds to determinants of the B72.3 antibody. Heat extraction of serum samples effectively eliminated interferences probably caused by anti-idiotypic antibodies, but did not affect real TAG-72.

\section{Introduction}

The monoclonal antibody B72.3 recognises a carbohydrate antigen on the tumour-associated glycoprotein 72 (TAG-72) which is expressed in the majority of human epithelial cancers, including adenocarcinomas of the stomach and ovary $(1-2)$. Because the antigen is released into the circulation by tumours, monitoring of serum TAG-72 is used for assessment of the course of disease of patients with gastric cancer (3). Furthermore it has been proposed as an additional marker in ovarian cancer patients (4). The serum concentration of TAG-72 can be measured by means of the immunometric "twosite sandwich" technique using the antibody B72.3 as both the capture and the detector antibody (5), or in an heterologous assay design with the monoclonal antibody CC49 (directed against a separate epitope on the TAG72 molecule) as capture antibody, and labelled B72.3 antibody for detection (6).

There have been a number of reports recently suggesting clinical use of immunoscintigraphy with the monoclonal antibody B72.3 for the management of patients with ovarian cancer $(7-8)$. It is well known that a percentage of patients after exposure to murine immunoglobulins develop human anti-murine antibodies which can interfere with diagnostic tests using murine antibodies. Among antibodies directed against determinants common to all murine antibodies (anti-iso/allotypic), antiidiotypic antibodies directed against idiotopes within the hypervariable region of the applied antibodies can also be formed (9-10). Anti-iso/allotypic human anti-murine antibodies interfere with all diagnostic tests involving murine antibodies $(11-14)$. In contrast, anti-idiotypic human anti-murine antibodies can interfere only in assays which use the antibody applied in vivo (or one that has an antigen binding site which cross-reacts with the anti-idiotypic human anti-murine antibodies). When this antibody is employed as both the capture and the detector antibody, anti-idiotypic antibodies can cause a falsely high assay response by cross-linking capture and detector antibodies $(15-16)$. While interference by anti-iso/ 
allotypic human anti-murine antibodies can be eliminated by addition of non-specific murine immunoglobulins (14), interference by anti-idiotypic human anti-murine antibodies can only be prevented by using capture (or detector) antibodies different from the antibody applied in vivo (17).

The aim of the present study was to evaluate the effect of repeated administration of the antibody B72.3 on the determination of TAG-72 when a homologous TAG-72 assay involving only B72.3 antibodies, or an heterologous assay involving CC49 capture and B72.3 detector antibodies, is used. We detected falsely high results after B72.3 infusion with both assays, obviously caused by human anti-B72.3 antibodies. We examined the specificity of the interfering antibodies and established a simple procedure to eliminate interference, which is suitable for routine measurement of TAG-72 in patients treated with the antibody B72.3.

\section{Materials and Methods}

\section{Patients and serum samples}

All serum samples examined were obtained routinely during follow up of ovarian cancer patients (Stage III/IV FIGO). The samples were aliquoted and stored at $-20^{\circ} \mathrm{C}$ until analysis.

One hundred and fifty two samples were drawn from 15 patients who had received one or more infusions of $1 \mathrm{mg}$ of the anti-TAG72 antibody B72.3 (Oncoscint; Eurocetus, Frankfurt, Germany). The procedures followed in this study were in accordance with the standards of the ethical committee of our faculty. Twenty five samples drawn from 6 of these patients before antibody treatment served as control. An additional 36 control samples were obtained from 13 other ovarian cancer patients not treated with murine antibodies.

\section{Determination of TAG-72}

TAG-72 was measured with the B72.3-M-K-S (Test 1; Sorin Biomedica, Düsseldorf, Germany) and the ELSA CA 72-4 (Test 2; Isotopen Diagnostik CIS, Dreieich, Germany). Both tests are solidphase immunoradiometric assays for TAG-72. In Test 1, the antibody B72.3 is used as both the immobilized and the labelled antibody. In Test 2 , the monoclonal anti-TAG-72 antibody CC49, which recognizes a separate epitope on the TAG-72 antigen (18), is used as immobilized antibody; the antibody B72.3 serves only as detector antibody. In Test 1 , bindings of both antibodies takes place simultaneously during a single incubation step. In Test 2 , the detector antibody is added after all serum components not bound to the capture antibody have been removed by an additional washing step. Both tests were performed according to the manufacturer's instructions.

\section{Determination of human serum IgG}

Human serum IgG was determined by radial immunodiffusion on LC-Partigen IgG plates (Behring, Marburg, Germany).

\section{Removal of interfering IgG from serum samples}

Interfering IgG were removed by affinity chromatography on Protein G-Sepharose (Pharmacia, Freiburg, Germany). We applied
$1 \mathrm{ml}$ of serum samples diluted 2-fold with phosphate buffer $(0.02$ $\mathrm{mol} / \mathrm{l}$ sodium phosphate, $\mathrm{pH} 7.0$ ) to the $3 \mathrm{ml}$ column equilibrated with phosphate buffer. After 5-minutes incubation at room temperature, the column was washed with $30 \mathrm{ml}$ phosphate buffer to elute the unadsorbed fraction. The adsorbed IgG fraction was eluted with $15 \mathrm{ml}$ of elution buffer $(0.1 \mathrm{~mol} / \mathrm{l}$ glycine- $\mathrm{HCl}, \mathrm{pH} 2.7)$. The eluate was neutralized immediately with $1.5 \mathrm{ml}$ neutralizing buffer (1 mol/l tris/hydroxymethyl)-aminomethane- $\mathrm{HCl}, \mathrm{pH}$ 9.0). Both the wash fraction as well as the eluate were concentrated using Centricon-30 concentrators (Amicon, Witten, Germany) to a final volume of $0.5 \mathrm{ml}$.

\section{Precipitation of serum IgG}

To eliminate interfering human antibodies, serum IgG was precipitated with perchloric acid or by a heat extraction procedure.

Precipitation with perchloric acid was carried out according to Kim et al. (19) with slight modification. Serum $(0.4 \mathrm{ml})$ was diluted with $0.4 \mathrm{ml} \mathrm{NaCl}(0.15 \mathrm{~mol} / \mathrm{l})$, then mixed with $0.8 \mathrm{ml}$ perchloric acid $(1.2 \mathrm{~mol} / \mathrm{l})$. The resulting precipitate was centrifuged at $1200 \mathrm{~g}$ for $10 \mathrm{~min}$, and $1.2 \mathrm{ml}$ of the supernatant was mixed in a separate test tube with $0.21 \mathrm{ml}$ of a mixture of $8.2 \mathrm{ml} \mathrm{KOH}(5 \mathrm{~mol} / \mathrm{l})+5.0$ $\mathrm{ml} \mathrm{K}_{2} \mathrm{HPO}_{4}(3 \mathrm{~mol} / \mathrm{l})$. The precipitated $\mathrm{KClO}_{4}$ was centrifuged at $1200 \mathrm{~g}$ for $10 \mathrm{~min}$ and the resulting supernatants were stored frozen at $-20^{\circ} \mathrm{C}$ until assay. Heat extraction was carried out according to $\mathrm{Kim}$ et al. (20) with slight modification. In disposable glass tubes, $0.2 \mathrm{ml}$ serum was mixed with $0.4 \mathrm{ml}$ sodium acetate buffer $(0.2 \mathrm{~mol} / \mathrm{l}$ sodium acetate, $\mathrm{pH} 5.0)$. The tubes were covered with glass beads and incubated for $10 \mathrm{~min}$ in a boiling water bath. At the end of incubation the samples were cooled on ice for $5 \mathrm{~min}$, then centrifuged at $1200 \mathrm{~g}$ for $10 \mathrm{~min}$. The supernatants were stored frozen at $-20^{\circ} \mathrm{C}$ until assay.

\section{Blocking of human anti-murine antibodies activity}

To block anti-iso/allotypic antibodies, non-specific murine IgG (Sigma, Deisenhofen, Germany) (0.01 ml; $16.6 \mathrm{~g} / \mathrm{l})$ was added to the native serum samples $(0.24 \mathrm{ml})$.

\section{Statistics and calculation}

Linear regression analysis was performed by means of the Passing \& Bablok method (21). As a measure of scatter of data points of the control collective, we calculated the geometric mean with the $99 \%$ tolerance interval for the ratio $X_{1} / Y_{1}$, where $X_{i}$ and $Y_{i}$ are the TAG-72 concentrations measured with the respective test kits in one sample as previously described (17). A data point $\left(\mathrm{X}_{\mathrm{a}} ; \mathrm{Y}_{\mathrm{a}}\right)$ was classified as deviating from the relationship of control samples when the ratio $X_{a} / Y_{a}$ exceeded the respective tolerance limits of the control collective.

\section{Results}

\section{Identification of samples containing} interfering antibodies

Serum samples obtained from patients after antibody treatment were screened for the presence of interfering anti-B72.3 antibodies by comparing the TAG-72 concentrations measured with the homologous. Test 1 and 
the heterologous Test 2. Figure 1 shows the results of TAG-72 determination with the two different tests for 60 control samples together with the respective $99 \%$ tolerance interval of the ratio $\mathrm{Xi} / \mathrm{Yi}$, compared with the results for 152 samples drawn after antibody treatment. After antibody treatment, $32 \%(49 / 152)$ of the samples gave discrepantly high results with Test 1 compared with Test 2.

Figure 2 shows the time relationship between the apparent TAG-72 concentrations measured with the homologous Test 1 and the heterologous Test 2, respectively, for a patient with no evidence of disease who received three antibody infusions. Ten days after the first infusion, the apparent TAG-72 concentration measured with Test 1 dramatically increased, while the values measured with Test 2 did not exceed $5 \mathrm{kU} / \mathrm{l}$. After the second and the third infusion, Test 1 showed additional increases up to a maximal value of $19900 \mathrm{kU} / \mathrm{l}$. With Test 2 a slight apparent increase of TAG-72 up to $88 \mathrm{kU} / 1$ was also

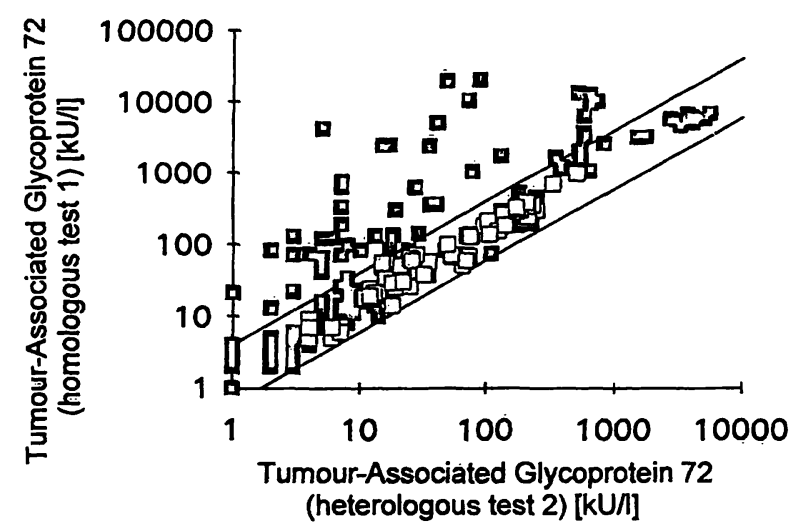

Fig. 1 Comparison of TAG-72 concentrations measured with the homologous Test 1 and the heterologous Test 2 in 60 control samples ( $\square$ ), and in 152 samples obtained from patients treated with the antibody B72.3 (a). The lines represent the limits of the $99 \%$ tolerance interval of the ratio $X_{i} / Y_{i}$ calculated for the control collective.

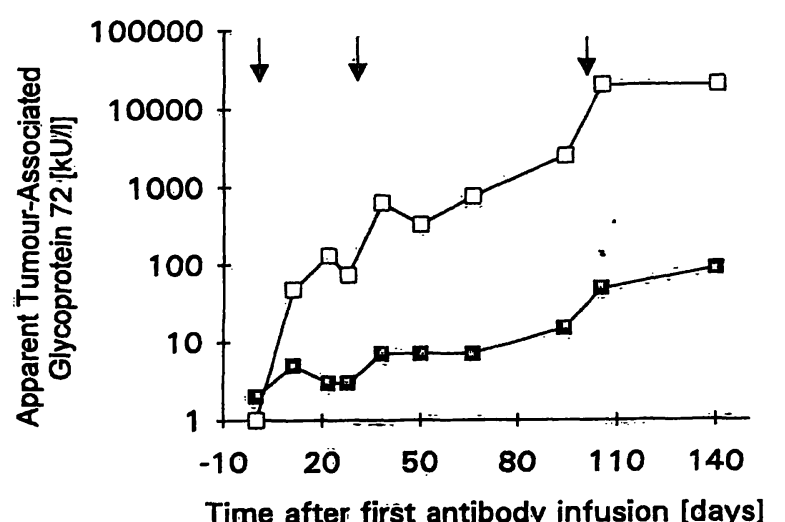

Fig. 2 Typical time course of apparent TAG-72 concentration measured with the homologous Test $1(\square)$ and the heterologous Test 2 (D) during repeated treatment with the antibody B72.3 in a patient with constant low real TAG-72 concentration. Arrows indicate the time of B72.3 infusions. measured. The fact that there was no clinical evidence of disease suggested that the increase of the TAG-72 concentration in both assays was false and that this was due to anti-B72.3 antibodies formed after infusion of the antibody B72.3.

To confirm that the observed interferences were indeed due to human anti-B72.3 antibodies, we attempted to remove possible interfering antibodies by means of affinity chromatography on protein G-Sepharose (tab. 1): using two serum samples from two patients after repeated antibody infusion, it was found that the TAG-72like material reacting with the homologous Test 1 was absorbed almost quantitatively by protein G-Sepharose; $77-81 \%$ of the applied TAG-72-like material was recovered in the subsequent eluate. Also, the TAG-72-like material reacting with the heterologous Test 2 was absorbed, and $80-98 \%$ was recovered in the subsequent eluate. In contrast, when a control sample was used, $70 \%$ and $78 \%$ of the TAG- 72 activity measured with Test 1 and Test 2, respectively, passed through the column, and no TAG-72 activity was found in the subsequent eluate. For all samples, serum IgG was absorbed quantitatively; $82-89 \%$ was recovered in the eluate.

\section{Elimination of interfering human anti-B 72.3 antibodies}

To establish a simple method for the elimination of interfering anti-B72.3 antibodies, we examined heat extraction as well as perchloric acid treatment of serum samples for their effects on interfering antibodies and real TAG-72. Both procedures effectively eliminated false positive TAG-72-like activity measured with Test 1 as well as Test 2 in two samples drawn after treatment with the antibody B72.3; the TAG-72 concentration of a control sample was not altered. Serum IgG was removed completely from all samples (tab. 2).

Because the heat extraction was easier to perform than the precipitation with perchloric acid, we measured the TAG-72 concentration of 10 further control samples before and after heat treatment to validate that this procedure did not affect real TAG-72. The TAG-72 concentrations measured in these samples (Test 1: 18-127 $\mathrm{kU} / \mathrm{l}$; Test $2: 11-137 \mathrm{kU} / \mathrm{l}$ ) were almost completely recovered after heat treatment with both Test 1 (mean recovery $97 \%$, range $78 \%-110 \%$ ) as well as Test 2 (mean recovery $101 \%$, range $81 \%-126 \%$ ) indicating that the real TAG-72 concentration was not affected.

Figure 3 shows the effect of heat treatment on the apparent TAG-72 of 11 samples with discrepantly high results in Test 1 compared with Test 2 . After heating, the apparent TAG-72 concentrations of the samples were reduced by $65-10400 \mathrm{kU} / \mathrm{l}$ measured with Test 1 and approxi- 
Tab. 1 Apparent TAG-72 measured with the homologous Test 1 and the heterologous Test 2, and scrum $\mathrm{IgG}$ in the fraction from Protein $\mathrm{G}$ affinity chromatography.

\begin{tabular}{|c|c|c|c|c|c|c|c|c|c|c|}
\hline & \multicolumn{3}{|c|}{ Sample No. $8751^{\mathrm{a}}$} & \multicolumn{3}{|c|}{ Sample No. $9084^{a}$} & & \multicolumn{3}{|c|}{ Sample No. $0288^{b}$} \\
\hline & \multicolumn{2}{|c|}{$\begin{array}{l}\text { Apparent TAG-72 } \\
\text { (U) }\end{array}$} & \multirow[t]{2}{*}{$\begin{array}{l}\mathrm{IgG} \\
(\mathrm{mg})\end{array}$} & \multicolumn{2}{|c|}{$\begin{array}{l}\text { Apparent TAG-72 } \\
\text { (U) }\end{array}$} & \multirow[t]{2}{*}{$\begin{array}{l}\text { IgG } \\
\text { (mg) }\end{array}$} & \multirow{2}{*}{$\therefore 1$} & \multicolumn{2}{|c|}{$\begin{array}{l}\text { Apparent TAG-72 } \\
\text { (U) }\end{array}$} & \multirow[t]{2}{*}{$\begin{array}{l}\mathrm{IgG} \\
\text { (mg) }\end{array}$} \\
\hline & Test 1 & Test 2 & & Test 1 & Test 2 & & & Test 1 & Test 2 & \\
\hline Applied to column & 9300 & 70 & 11.0 & 2560 & 35 & 7.4 & & 686 & 326 & 6.5 \\
\hline $\begin{array}{l}\text { Wash fraction } \\
\text { Recovery (\%) }\end{array}$ & $\begin{array}{l}56 \\
<1\end{array}$ & $\begin{array}{l}2 \\
3\end{array}$ & n.d. & $\begin{array}{r}5 \\
<1\end{array}$ & $\begin{array}{l}2 \\
6\end{array}$ & $\begin{array}{l}\text { n.d. } \\
-\end{array}$ & & $\begin{array}{r}481 \\
70\end{array}$ & $\begin{array}{r}255 \\
78\end{array}$ & n.d. \\
\hline $\begin{array}{l}\text { Eluate } \\
\text { Recovery (\%) }\end{array}$ & $\begin{array}{r}7200 \\
77\end{array}$ & $\begin{array}{l}69 \\
98\end{array}$ & $\begin{array}{l}9.0 \\
82\end{array}$ & $\begin{array}{r}2080 \\
81\end{array}$ & $\begin{array}{l}28 \\
80\end{array}$ & $\begin{array}{l}6.6 \\
89\end{array}$ & & n.d. & n.d. & $\begin{array}{l}5.7 \\
88\end{array}$ \\
\hline
\end{tabular}

a Draivn from two different patients 10 days after the third (No. ${ }^{b}$ Control patient

8751 ) and 79 days after the second (No. 9084) infusion of B72.3 n.d., None detected

antibody, respectively

Tab. 2 Effect of heat extraction and perchloric acid treatment on apparent TAG-72 values measured with the homologous Test 1 and the heterologous Test 2, and on serum IgG.

\begin{tabular}{|c|c|c|c|c|c|c|c|c|c|}
\hline \multirow[t]{3}{*}{ Sample treatment } & \multicolumn{3}{|c|}{ Sample No. $9086^{\mathrm{a}}$} & \multicolumn{3}{|c|}{ Sample No. $9288^{a}$} & \multicolumn{3}{|c|}{ Sample No. $0589^{b}$} \\
\hline & \multicolumn{2}{|c|}{$\begin{array}{l}\text { Apparent TAG-72 } \\
(\mathrm{kU} / \mathrm{l})\end{array}$} & \multirow[t]{2}{*}{$\begin{array}{l}\operatorname{IgG} \\
(\mathrm{g} / 1)\end{array}$} & \multicolumn{2}{|c|}{$\begin{array}{l}\text { Apparent TAG-72 } \\
(\mathrm{kU} / \mathrm{l})\end{array}$} & \multirow[t]{2}{*}{$\begin{array}{l}\text { IgG } \\
(\mathrm{g} / \mathrm{l})\end{array}$} & \multicolumn{2}{|c|}{$\begin{array}{l}\text { Apparent TAG-72 } \\
(\mathrm{k} \cup \dot{U} / 1)\end{array}$} & \multirow[t]{2}{*}{$\begin{array}{l}\mathrm{IgG} \\
(\mathrm{g} / \mathrm{I}\end{array}$} \\
\hline & Test 1 & Test 2 & & Test 1 & Test 2 & & Test 1 & Test 2 & \\
\hline None & 15700 & 72 & 19.1 & 2400 & 35 & 4.5 & 66 & 54 & 16.9 \\
\hline Heat extraction & 7 & 3 & n.d. & 10 & 7 & n.d. & 69 & 52 & n. d. \\
\hline Acid precipitation & 17 & 8 & n. d. & 19 & 11 & n.d. & 66 & 50 & n. d. \\
\hline
\end{tabular}

a Drawn from two different patients 70 days after the third (No. 9086) and 112 days after the second (No. 9288) infusion of B72.3 antibody, respectively

b Control patient n. d., None detected mately 6-100 kU/1 measured with Test 2 . All discrepant results were corrected, indicating that interference was effectively eliminated.

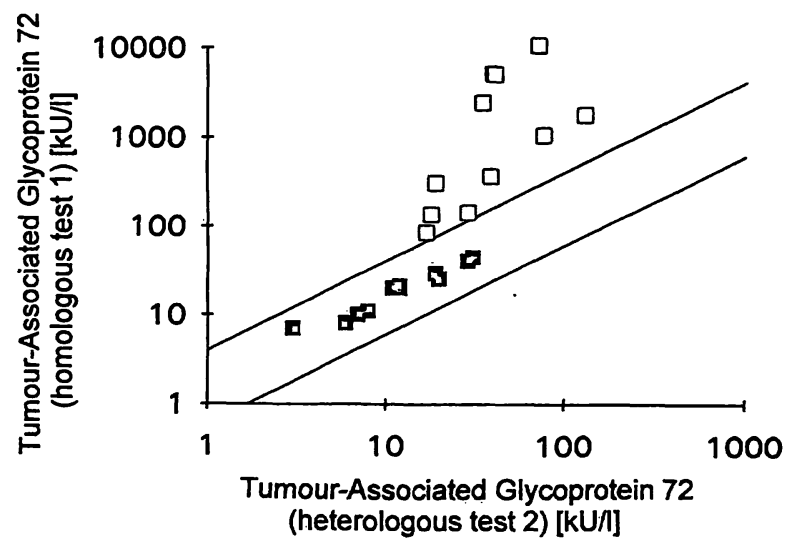

Fig. 3 Comparisons of apparent TAG-72 concentrations measured with the homologous Test 1 and the heterologous Test 2 in 11 discrepant samples before $(\square)$ and after $(\mathbb{\nabla})$ heat extraction. The。 lines represent the limits of the $99 \%$ tolerance interval of the ratio $\mathrm{X}_{\mathrm{i}} / \mathrm{Y}_{\mathrm{i}}$ calculated for the control collective.

\section{Specificity of interfering anti-B 72.3 antibodies}

To examine the specificity of the interfering IgG we attempted to suppress the falsely high TAG-72 values by adding increasing amounts of non-specific mouse IgG. In three serum samples the falsely high TAG-72 values measured with Test 1 as well as Test 2 were only partly suppressed by addition of $0.67 \mathrm{~g} / \mathrm{l}$ non-specific mouse IgG (tab. 3); the values measured in control samples were not affected. When the samples were prediluted to a TAG-72 concentration in the measuring range of Test 1 , a maximal reduction of $24-40 \%$ was attained with $0.07 \mathrm{~g} / 1$ mouse IgG. Larger amounts of mouse $\mathrm{IgG}$ did not further reduce the apparent TAG-72 concentration (fig. 4), indicating the antiidiotypic nature of a high percentage of the interfering anti-B72.3 antibodies.

\section{Discussion}

This study demonstrates that in a significant number of serum samples obtained from iovarian cancer patients af- 
Tab. 3 Effect of addition of non-specific murine IgG or heat extraction on apparent TAG-72 values measured with the homologous Test 1 and the heterologous Test 2.

\begin{tabular}{|c|c|c|c|c|c|c|}
\hline \multirow{3}{*}{ Sample treatment } & \multirow{2}{*}{\multicolumn{2}{|c|}{$\begin{array}{l}\text { Sample No. } 9086^{\mathrm{a}} \\
\text { Apparent TAG-72 } \\
(\mathrm{kU} / \mathrm{l})\end{array}$}} & \multirow{2}{*}{\multicolumn{2}{|c|}{$\begin{array}{l}\text { Sample No. } 9084^{\mathrm{a}} \\
\text { Apparent TAG-72 } \\
(\mathrm{kU} / \mathrm{l})\end{array}$}} & \multirow{2}{*}{\multicolumn{2}{|c|}{$\begin{array}{l}\text { Sample No. } 7103^{a} \\
\text { Apparent TAG-72 } \\
(\mathrm{kU} / \mathrm{l})\end{array}$}} \\
\hline & & & & & & \\
\hline & Test 1 & Test 2 & Test 1 & Test 2 & Test 1 & Test 2 \\
\hline None & 15700 & 72 & 3905 & 39 & 632 & 62 \\
\hline Mouse IgG added & 11900 & 48 & 3820 & 20 & 449 & 29 \\
\hline Heat extraction & 7 & 3 & 8 & 6 & 44 & 31 \\
\hline
\end{tabular}

a Drawn from three different patients, 70 (No. 9086) and 10 (No. 7103) days after the third and 79 days after the second (No. 9084) infusion of B72.3 antibody, respectively

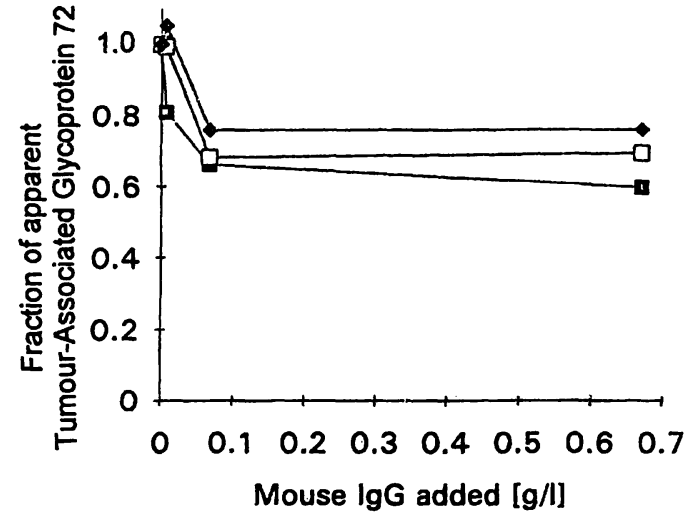

Fig. 4 Effect of addition of increasing amounts of non-specific murine IgG on apparent TAG-72 values measured with the homologous Test 1 in serum samples drawn from three different patients $10(\square)$ and $70(\Delta)$ days after the third, and 79 days after the second (ㅁ) infusion of B72.3 antibodies. Apparent TAG-72 of the three samples was reduced after heat extraction by more than $93 \%$.

ter infusion of the antibody B72.3, falsely high TAG-72 values are measured with an homologous TAG-72 assay (Test 1) involving only B72.3 antibodies and also to a lesser degree with an heterologous assay (Test 2) involving CC49 capture antibodies. The fact that the interfering agents could be absorbed by protein $G$ and were precipitated together with serum IgG, as well as the relationship between the time of antibody infusions and the appearance of interference, strongly suggests that the responsible serum components are human IgG induced and boosted by injection of B $\mathbf{7} 2.3$ antibodies.

The strong interference observed with the homologous Test 1 is probably caused to a large extent by anti-idiotypic anti-B72.3 antibodies, which bind specifically to B72.3 antibodies, and have no or at least only low affinity to the anti-TAG-72 antibody CC49, resulting in only slight interference with the heterologous Test 2 . This hypothesis is confirmed by the fact that murine IgG only partly suppressed falsely high values in Test 1 . However, the false positive values, measured with Test 2 in samples with high false positive TAG-72 values in Test 1 , could not be suppressed completely by addition of murine IgG, suggesting that the CC49 antibodies slightly cross-react with anti-idiotypic anti-B72.3 antibodies.

Similar interference by anti-idiotypic antibodies has been observed for the determination of the tumour-associated antigen $C A 125$. In patients treated with the antiCA 125 antibody $\mathrm{OC} 125$, falsely high CA 125 values were measured with an homologous assay involving OC125 as both capture and detector antibody, which could not be blocked or absorbed by non-specific murine IgG (15-16). The falsely high values were not observed when an heterologous assay with a different capture antibody was used (17).

While anti-iso/allotypic human anti-murine antibodies can be blocked by non-specific murine IgG, interferences by anti-idiotypic antibodies can only be eliminated by removing the interfering antibodies. Different methods are proposed for removing interfering serum IgG, including affinity chromatography on Protein A, Protein $G$ or anti-human $\operatorname{IgG}(13,15-17)$, precipitation with polyethylene glycol (13) or perchloric acid (19), and heating to $90^{\circ} \mathrm{C}(13)$. It has been reported previously that TAG-72 is heat-stable and soluble in perchloric acid (22-23). This is in accordance with our results, which show that the TAG-72 concentrations measured in the control samples were not affected by heating to $100^{\circ} \mathrm{C}$ or precipitation with perchloric acid, whereas interfering human anti-B72.3 was effectively removed by both procedures. Our data demonstrate that in samples containing interfering anti-B72.3 antibodies, the TAG-72 concentration can be determined correctly after pretreatment by heat extraction. However, the samples are diluted during heat extraction (3-fold) and precipitation with perchloric acid (4.7-fold), which decreases the analytical sensitivity of the measurement.

When the TAG-72 concentration is monitored in patients treated with the antibody B72.3, one should be aware of the possibility of interference from newly formed anti- 
B72.3 antibodies. To exclude this interference, samples obtained after infusion of antibodies should be pretreated to remove interfering serum IgG.

\section{References}

1. Thor, A., Ohuchi, N., Szpak, C. A., Johnston, W. W. \& Schlom, J. (1986) Distribution of oncofetal antigen tumor-associated glycoprotein-72 defined by monoclonal antibody B72.3. Cancer Res. 46, 3118-3124.

2. Thor, A., Gorstein, F., Ohuchi, N., Szpak, C. A., Johnston, W. W. \& Schlom, J. (1986) Tumor associated glycoprotein (TAG72) in ovarian carcinomas defined by monoclonal antibody B72.3. J. Natl. Cancer. Inst. 76, 995-1006.

3. Guadagni, F., Roselli, M., Amato, T., Cosimelli, M., Perri, P., Casale, V., Carlini, M., Santoro, E., Cavaliere, R., Greiner, J. W. \& Schlom, J. (1992) CA-72-4 measurement of tumorassociated glycoprotein-72 (TAG-72) as a serum marker in the management of gastric carcinoma. Cancer Res. 52, 12221227.

4. Esposito, G., Panza, N., Mansi, L., De Matteis, A., D'Aiuto, G., Labonia, V., Riccardi, F., Pacilio, G. \& Salvatore, M. (1990) Evaluation of TAG 72 as a serum marker in ovarian and breàst carcinoma. J. Nucl. Med. Allied. Sci. 34, 88-93.

5. Paterson, A. J., Schlom, J., Sears, N. F., Bennett, J. \& Colcher, D. (1986) A radioimmunoassay for the detection of a human tumor-associated glycoprotein (TAG-72) using monoclonal antibody B72.3. Int. J. Cancer 37, 650-658.

6. Gero, E. J., Colcher, D., Ferroni, P., Melsheimer, R., Giani, S., Schlom, J. \& Kaplan, P. (1989) CA 72-4 radioimmunoassay for the detection of the TAG-72 carcinoma-associated antigen in serum of patients. J. Clin. Lab. Anal. 3, 360-369.

7. Mansi, L., Panza, N., Lastoria, S., Pacilio, G. \& Salvatore, M. (1989) Diagnosis of ovarian cancer with radiolabeled monoclonal antibodies. Int. J. Rad. Appl. Instrum. 16, 127-135.

8. Krag, D. N., Ford, P., Smith, L., Taylor, M., Schneider, P. D., Bushberg, J. T. \& Goodnight, J. E. (1993) Clinical immunoscintigraphy of recurrent ovarian cancer with indium 111-labeled B72.3 monoclonal antibody. Arch. Surg. 128, 819-823.

9. Dillman, R. O. (1990) Human antimouse and antiglobulin response to monoclonal antibodies. Antibody Immunoconj. Radiopharm. 3, 1-15.

10. Tjandra, J. J., Ramadi, U. \& McKenzie, F. C. (1982) Development of human anti-murine antibody (HAMA) response in patients. Immunol. Cell. Biol. 68, 367-376.

11. Howanitz, P. J., Howanitz, J. H., Lamberson, H. V. \& Ennis, K. M. (1982) Incidence and mechanism of spurious increases in serum thyrotropin. Clin. Chem. 28, 427-431.

12. Thompson, R. J., Jackson, A. P. \& Langlois, N. (1986) Circulating antibodies to mouse monoclonal immunoglobulins in normal subjects - incidence, species specificity, and effects on a two-site assay for creatinine kinase-MB isoenzyme. Clin. Chem. 32, 476-481.

13. Primus, F. J., Kelly, E. A., Hansen, H. J. \& Goldenberg, D. M. (1988) "Sandwich"-type immunoassay of carcinoembryonic

\section{Acknowledgement}

We thank Dietlind Ackermann for excellent technical assistance. antigen in patients receiving murine monoclonal antibodies for diagnosis and therapy. Clin. Chem. 34, 261-264.

14. Boscato, L. M. \& Stuart, M. C. (1988) Heterophilic antibodies: a problem for all immunoassay. Clin. Chem. 34, 27-33.

15. Reinsberg, J., Heydweiller, A., Wagner, U., Pfeil, K., Oehr, P. \& Krebs, D. (1990) Evidence for interaction of human antiidiotypic antibodies with CA 125 determination in a patient after radioimmunodetection. Clin. Chem. 36, 164-167.

16. Turpeinen, U., Lehtovirta, P., Alfthan, H. \& Stenman, U. H. (1990) Interference by human anti-mouse antibodies in CA 125 assay after immunoscintigraphy: Anti-idiotypic antibodies not neutralized by mouse IgG but removed by chromatography. Clin. Chem. 36, 1333-1338.

17. Reinsberg, J., Schultes, B., Wagner, U. \& Krebs, D. (1993) Monitoring of CA 125 in serum of ovarian cancer patients after administration of ${ }^{13 !} \mathrm{I}-\mathrm{F}\left(\mathrm{ab}^{\prime}\right)_{2}$ fragments of the $\mathrm{OCl} 25$ antibody. Clin. Chem. 39, 891-896.

18. Muraro, R., Kuroki, M., Wunderlich, D., Poole, D. J., Colcher, D., Thor, A., Greine, J. W., Simpson, J. F., Molinolo, A., Noguchi, P. \& Schlom, J. (1988) Generation and characterization of B72.3 second generation monoclonial antibodies reactive with the tumor-associated glycoprotein 72 antigen. Cancer Res. 48, 45884596.

19. Kim, Y. D., Tomita, J. T. \& Schenck, J. R. (1978) A simplified solid-phase radioimmunoassay of carcinoembryonic antigen. J. Immunol. Meth. 19, 309-316.

20. Kim, Y. D., Tomita, J. T., Schenck, J. R., Moeller, C., Weber, G. F. \& Hịata, A. A. (1979) Extraction of human pläsma or sera by heat treatment for a solid-phase radioimmunoassay of carcinoembryonic antigen. Clin. Chem. 25, 773-776.

21. Bablok, W., Passing, H., Bender, R. \& Schneider, B. (1988) A general regression procedure for method transformation. J. Clin. Chem. Clin. Biochem: 26, 783-790.

22. Katari, R. S., Fernsten, P. D. \& Schlom, J. (1990) Characterization of the shed form of the human tumor-associated glycoprotein (TAG-72) from serous effusions of patients with different types of carcinomas. Cancer Res. 50, 4885-4890.

23. Sheer, D. G., Schlom, J. \& Cooper, H. L. (1988) Purification and composition of the human tumor-associated glycoprotein (TAG-72) defined by monoclonal antibodies CC49 and B72.3. Cancer Res. 48, 6811-6818.

\section{Dr. J. Reinsberg}

Zentrum für Frauenheilkunde und Geburtshilfe Universität Bonn

Sigmund-Freud-Straße 25

D-53127 Bonn

Germany 